\title{
EVALUATION OF ASPECT RATIO (1/d) OF BAMBOO FIBRE AS A REINFORCEMENT MATERIAL IN CONCRETE
}

\author{
Mahesh S M ${ }^{1}$, Kavitha.S \\ ${ }^{I}$ PG Student, ACS college of Engineering, Kambipura Bangalore, Karnataka, India \\ ${ }^{2}$ Assistant Professor, ACS College of Engineering, Kambipura Bangalore, Karnataka, India
}

\begin{abstract}
Fibres are commonly used in concrete to control the cracks, shrinkage and to improve the strength and performance of the concrete. Generally various types of fibres are used like natural and artificial fibres in the concrete mix to produce the expected strength and crack resistance. an attempt is made to innovate a natural, eco friendly fibre which is available to the common man. In this paper, tests are carryout on bamboo fibre reinforced concrete to evaluate aspect ratio ( $1 / d)$ of bamboo fibres. Different ages of bamboo is collected, the extraction of fibres is done by mechanical method. Once the bamboo fibres are extracted the various lengths and diameters are selected and SEM analysis is carried out to find out the microstructure of bamboo fibres to know the failure analysis .these selected bamboo fibres add at the fixed rate of $0.1 \%$ to $1.5 \%(0.5,0.75,1,1.25,1.5)$ by the cement weight to the concrete mix. Then the samples of cubes, beams and cylinders are casted from the concrete mix and curing will be done for required period. Experimental investigations are carried out using most commonly used tests in laboratory, which includes concrete workability test, compressive test, split tensile test, and test for flexure from the various test results the aspect ratio ( $/ / d$ ratio) and also the effectiveness of bamboo fibres usage in concrete has been evaluated.
\end{abstract}

Keywords: Bamboo fibre, Aspect ratio, Structure, Extraction, SEM analysis.

\section{INTRODUCTION}

Egyptians has developed this concept of using the fibres in the concrete mix as a reinforcing material. Before they used to mix the straw and hairs of animals in the concrete as a material of reinforcement for fixing of bricks in walls. The production of fibres is also in less percentage and to give potentiality to this by providing a land to improve this is very necessary. So that there is a similar way is to extracting the fibre is the major problem. To that problem the only solution is these bamboo fibres. This is bamboo is not grass or not a wood, but it is having the characteristics of both the grass and wood. In the recent years the concept of fibre reinforcement concrete is a great development to enhance effectiveness and grater performance related results in concrete it is much necessary to produce the high strength, performance and durability with desirable aspect ratio from which the effectiveness and the good results of performance are to developed in the concrete. The main reason of using the natural fibres to providing the greater strength and good resistance capacity to structures and to achieve the greater performances from it by making the structures rigid. The fibres are mixed randomly in the concrete mix with the calculated percentages of contents of the fibre reinforced concrete. The characteristics of the fibres and materials should effects on the results of fibre reinforced concrete. Whereas results are depends on the types of fibres used, shape of fibres, percentage content mix in concrete and the method of mixing fibres in concrete, the size of the aggregate, shape and texture of the aggregate. The fibres are the pieces of small size materials used for reinforcement which may be available naturally or manufactured artificially. The fibres may be flat in shape, triangle or may be in circular shape. The property of the fibre is often defined by the parameter which is known as "Aspect Ratio". The ratio of fibre length to the fibre diameter is called as aspect ratio.The length of the fibre is decided by the multiplying the diameter to the aspect ratio. This length will be influences on the strength of fibres which may in flexure, compression and may be tension.

\section{Advantages of Bamboo Fibre}

- Bamboo fibre is a naturally available material which can compare with glass fibre because of its characteristic properties.

- Bamboo fibres are locally available material at low cost.

- Bamboo fibres having low density, eco friendly, sustainability and biodegradability as compared to other natural plant fibres.

- Bamboo fibre reinforced concrete can be a total cost effective.

- $\quad$ Fibres are more effective in crack control.

\section{MATERIALS USED AND THEIR PROPERTIES}

The materials used in the present experimental programme are as follows:

- Ordinary Portland Cement (53 grade)

- $\quad$ Sand (zone 2 as per IS 383:1970)

- $\quad$ Coarse aggregate (as per IS 383:1970)

- Bamboo fibre ( $1 / \mathrm{d}$ has to fix) naturally extracted. 
(1) Cement (53-grade OPC): The cement consists of preliminary percentage of silicates and some percentage of lime aluminates. On this experiment 53-grade ordinary Portland cement manufacturer Adithya birla was used for the all mixes. The cement used was contemporary with none lumps.

(2) Coarse aggregates: Locally available crushed granite aggregate which are passing from the IS sieve size of 20 $\mathrm{mm}$ and which are retaining in the IS sieve size of 12.5 $\mathrm{mm}$ are to be generally used for the construction. The coarse aggregates used were confirming to IS 383:1970. The highest size and grading of the aggregates depends on the special applications.

(3) Fine aggregates: Locally available high quality sand gathered from river bed, that should be pass from IS sieve $4.75 \mathrm{~mm}$ and the same will be for all of the mixes of concrete. The fine aggregate which is having fineness modulus 2.81 is used were confirming to zone II according to IS code.

(4) Bamboo fibres: Bamboo fibres are the naturally available fibres which are available locally. These are different age which varies in the strength when they are used in the concrete mix as a reinforcing material. The bamboos are having a good length, which can give good characteristics when it has been used as a reinforcing material. In structure these are hollow long structures which consist of rings. In between the two rings they will be having a structure called as Internodes. From these internodes the branches will be grown.

The internal structures of the bamboo will be consisting of conducting tissues those are parenchyma cells and the sclerenchyma cells. These parenchyma cells consist of vascular bundles. These vascular bundles will be having a major part in the strength. The strength of the bamboo fibres has been decided by the number of vascular bundles present in it. Higher the vascular bundles higher the strength of fibres. The bamboos of different ages are shown in following figure.

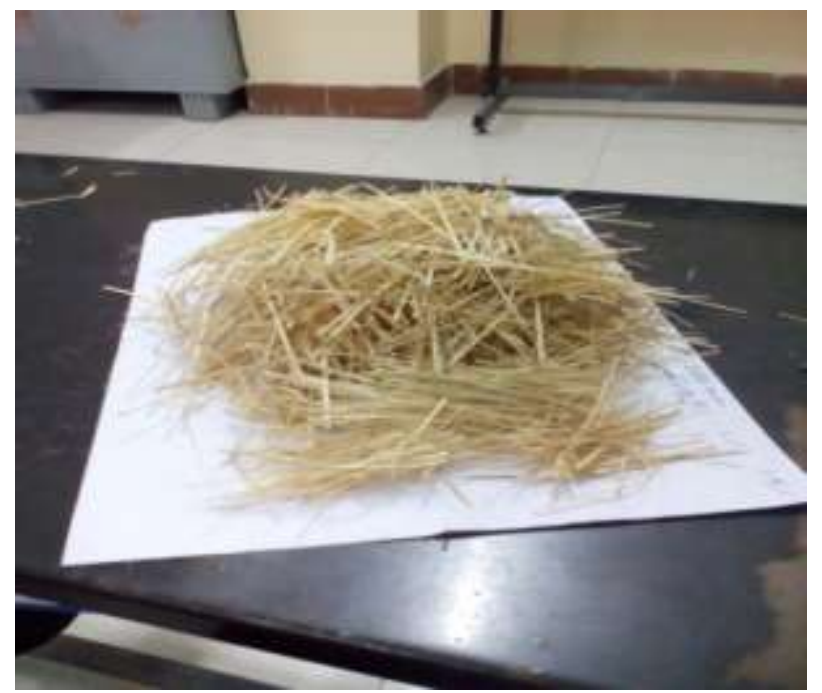

Fig 1 Natural bamboo fibres

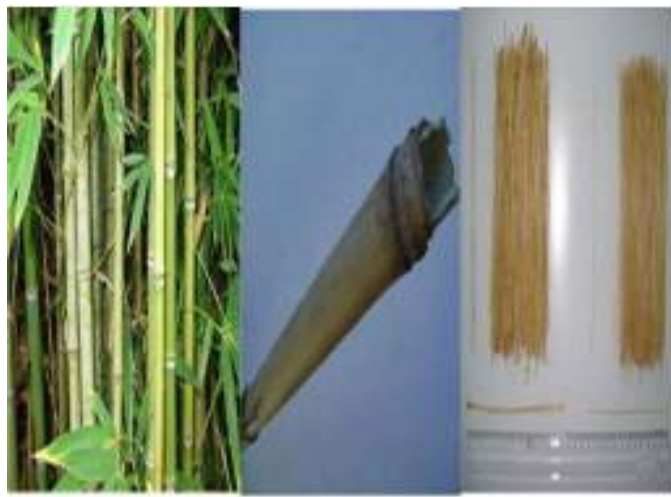

Fig 2 Processing of bamboo fibres

\section{EXTRACTION METHODS}

Generally there is less ideas and minimum knowledge about the these extracting of bamboo fibre, and also there is only less number of studies and investigations are carried out. The commonly used method in extracting fibre is,

a) Extraction by Mechanical method

b) The alkali treat method

c) Steam Explosion method

In this work I have used the mechanical extraction method of natural fibre.

a) Extracting by mechanical method: In this method the young bamboo of age two to eight months is selected and it is cleaved vertically into number of strips. Those strips are taken into roller to lose the strips and they will drive under the roller. After rolling that strips are to be boiled for ten hours at $900 \mathrm{C}$. Later these strips will dried and the small pieces of fibres are to be extracted.

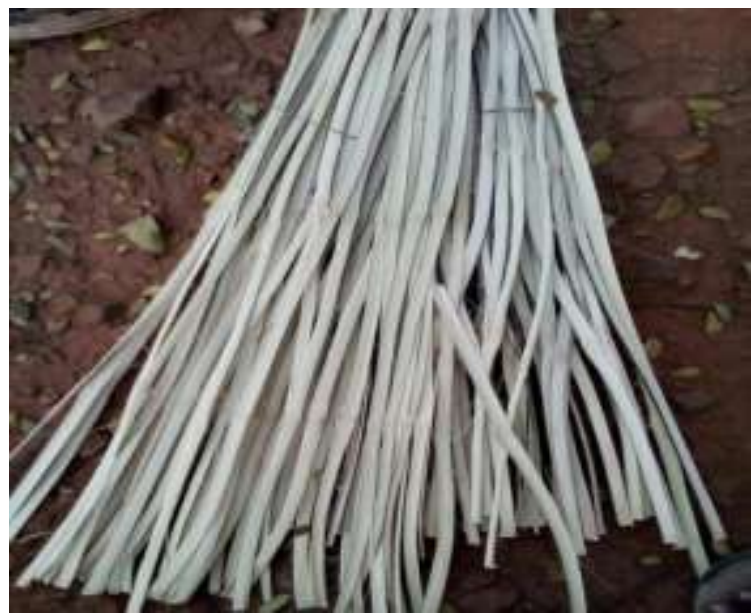

Fig 3 Cleaved young age bamboo strips 


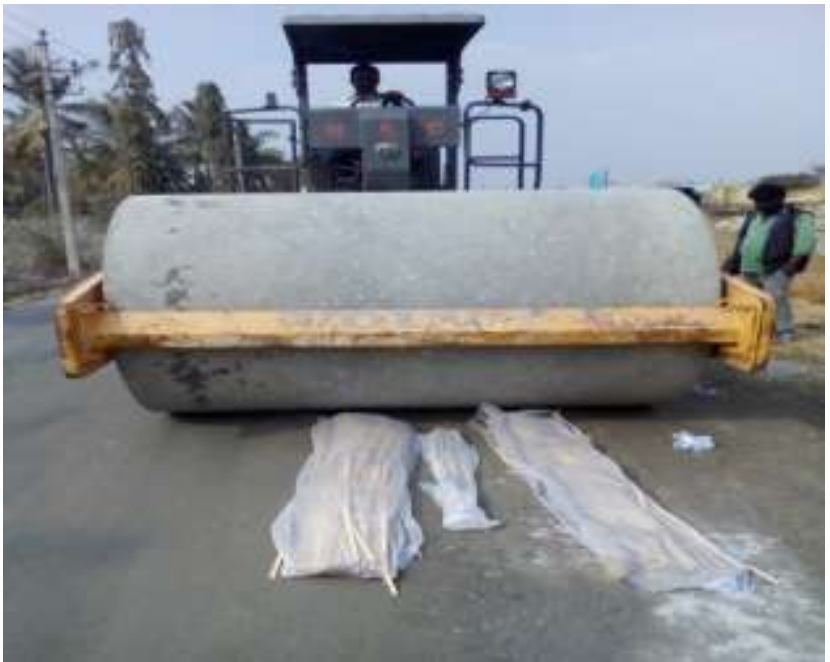

Fig 4 Crushing of bamboo strips by roller

\section{SEM ANALYSIS TEST}

Scanning electron microscopy test has been conducted to examine the micro structure of bamboo fibre and failure analysis as well as the diameter of bamboo fibre.

\section{Observations}

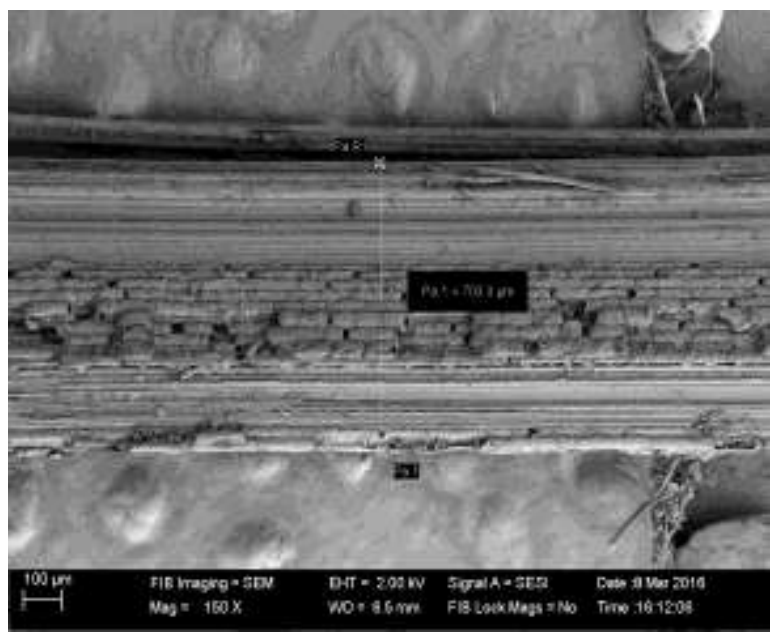

Fig 6 Scanning Electron Microscoping image of bamboo fibre diameter 700 micron

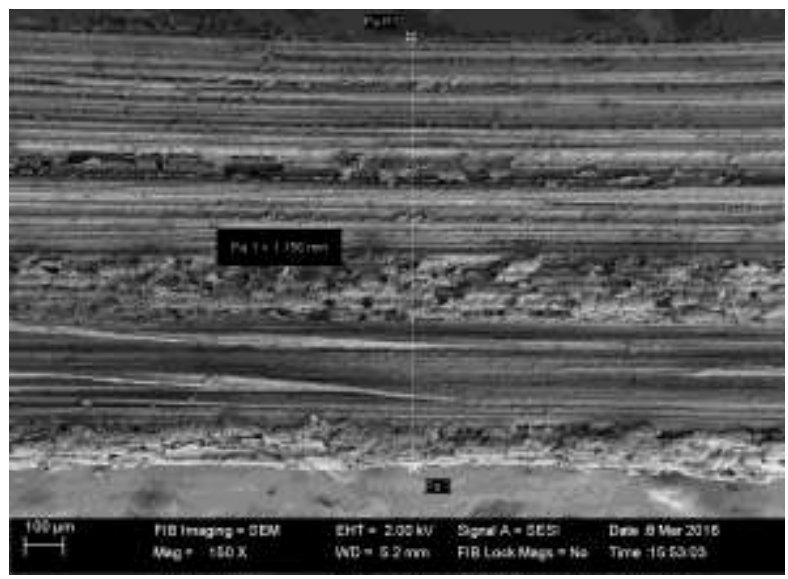

Fig 7 Scanning Electron Microscoping image of bamboo fibre of diameter $1.156 \mathrm{~mm}$

\section{RESULTS AND DISCUSSIONS:}

a) Compressive strength: It is noted from table 1 that the 28 days compressive strength for bamboo fibres based on M30 grade bamboo fibre reinforced concrete is $44.23 \mathrm{Mpa}$ which is obtained at $1 \%$ of fibres mixed with concrete of diameters of fibres is of $1.244 \mathrm{~mm}$ with an aspect ratio $(1 / \mathrm{d})$ of 40 .

Table 1 Results of 28 days compressive strength of BFRC D1 (diameter $1.244 \mathrm{~mm}$ )

\begin{tabular}{|l|l|l|l|l|}
\hline \multirow{2}{*}{ No } & \multirow{2}{*}{ Description } & \multicolumn{3}{|l|}{$\begin{array}{l}\text { 28 days Compressive } \\
\text { strength(N/mm }\end{array}$} \\
\cline { 3 - 5 } & & $(\mathbf{l} / \mathbf{d}) \mathbf{3 0}$ & $(\mathbf{l} / \mathbf{d}) \mathbf{4 0}$ & $(\mathbf{l} / \mathbf{d}) \mathbf{5 0}$ \\
\hline 1 & $0.5 \%$ fibre & 36.6 & 41.3 & 38 \\
\hline 2 & $0.75 \%$ fibre & 37.2 & 42.53 & 39.6 \\
\hline 3 & $1 \%$ fibre & 38.3 & 44.23 & 41.3 \\
\hline 4 & $1.25 \%$ fibre & 37.9 & 43.3 & 40.9 \\
\hline
\end{tabular}

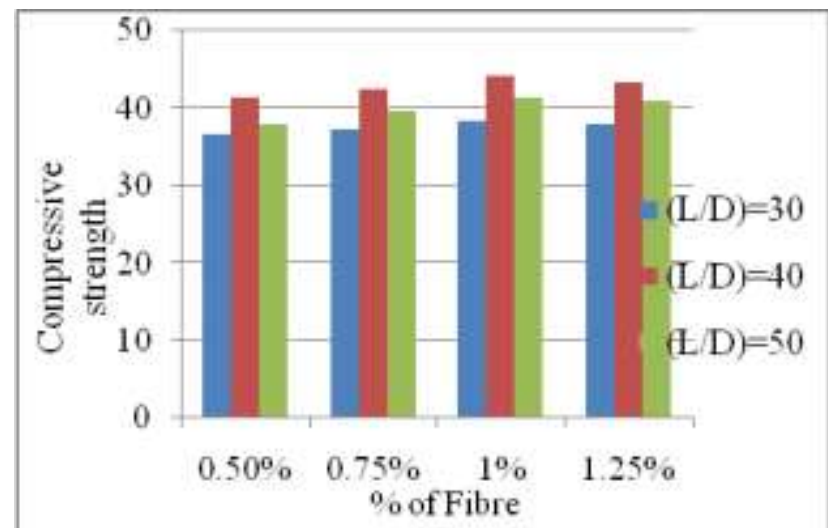

Fig 828 days Compressive strength of BFRC D1 (diameter $1.244 \mathrm{~mm})$

b) Split tensile Strength: It is noted from table 8 that the 28 days tensile strength for bamboo fibre based on M30 grade bamboo fibre reinforced concrete is $5.1 \mathrm{Mpa}$ which is obtained at $1 \%$ of fibre mixed with concrete of diameters of fibre is of $1.244 \mathrm{~mm}$ with an aspect ratio $(1 / \mathrm{d})$ of 40 .

Table 2 Results of 28 days split tensile strength for BFRC D1 (diameter $1.244 \mathrm{~mm}$ )

\begin{tabular}{|c|c|c|c|c|}
\hline \multirow[t]{2}{*}{ No } & \multirow[t]{2}{*}{ Description } & \multicolumn{3}{|c|}{$\begin{array}{l}28 \quad \text { days } \\
\text { strength }\left(\mathrm{N} / \mathrm{mm}^{2}\right)\end{array}$} \\
\hline & & (l/d) 30 & (l/d) 40 & (l/d) 50 \\
\hline 1 & $0.5 \%$ fibre & 3.7 & 4 & 3.9 \\
\hline 2 & $0.75 \%$ fibre & 3.8 & 4.1 & 4 \\
\hline 3 & $1 \%$ fibre & 3.9 & 5.1 & 4.6 \\
\hline 4 & $1.25 \%$ fibre & 3.75 & 4.8 & 4.3 \\
\hline
\end{tabular}




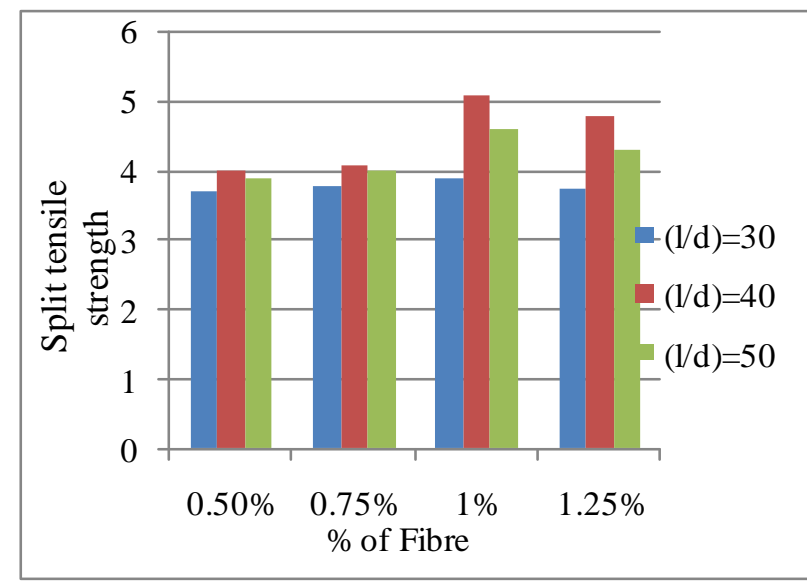

Fig 928 days Flexural strength of BFRC D1 (diameter $1.244 \mathrm{~mm})$

c) Flexural strength: It is noted from table 3 that the 28 days flexural strength for bamboo fibre based on M30 grade bamboo fibre reinforced concrete is $15.3 \mathrm{Mpa}$ which is obtained at $1 \%$ of fibre mixed with concrete of diameters of fibre is of $1.244 \mathrm{~mm}$ with an aspect ratio (1/d) of 40 .

Table 3 Results of 28 days Flexural strength for BFRC D1 (diameter 1.244)

\begin{tabular}{|c|c|c|c|c|}
\hline \multirow[t]{2}{*}{ No } & \multirow[t]{2}{*}{ Description } & \multicolumn{3}{|c|}{$\begin{array}{l}28 \quad \text { days } \\
\text { strength }\left(\mathrm{N} / \mathrm{mm}^{2}\right)\end{array}$} \\
\hline & & (l/d) 30 & (l/d) 40 & (l/d) 50 \\
\hline 1 & $0.5 \%$ fibre & 12.5 & 13 & 12.8 \\
\hline 2 & $0.75 \%$ fibre & 13.1 & 13.6 & 13.5 \\
\hline 3 & $1 \%$ fibre & 13.4 & 15.3 & 14.6 \\
\hline 4 & $1.25 \%$ fibre & 13.2 & 14 & 13.9 \\
\hline
\end{tabular}

20

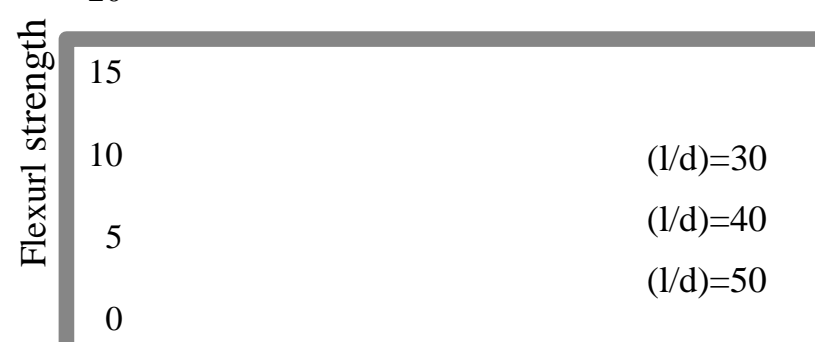

$0.50 \% \quad 0.75 \% \quad 1 \% \quad 1.25 \%$

Fig 1028 days Flexural strength of BFRC D1 (diameter $1.244 \mathrm{~mm})$

\section{CONCLUSION}

A innovative natural, eco friendly fibre is introduced to the field of concrete to enhance the tensile and torsion properties. Bamboo fibre is one which is of low cost and to produce high strength concrete. Keeping focus on substitution for natural plants fibre, as they having the advantages such as very less cost, density is lower, friendly with environment. The fibre reinforced concrete with different fibre ratios has given tremendous results compared normal concrete. Greater compressive strength has been obtained when $1 \%$ of fibre mixed with concrete of aspect ratio (1/d) 40 when compared to $0 \%, 5 \%, .75 \%$, and $1.25 \%$.The maximum Split tensile strength is obtained with $1 \%$ of fibre with aspect ratio of (1/d) 40 when compared to $0 \%, 5 \%, .75 \%$, and $1.25 \%$.The maximum flexural strength is obtained with $1 \%$ of fibres with aspect ratio of (1/d) 40 when compared to $0 \%, 5 \%, .75 \%$, and $1.25 \%$.From the experimental investigations aspect ratio (1/d) 40 has given the maximum results with $1 \%$ of fibre content.

\section{REFERENCES}

[1] Nguyen Tien Phong, Toru Fujii, Bui Chuong, Kazuya Okubo, Doshisha University, Japan Study on How to Effectively Extract Bamboo Fibres from Raw Bamboo and Wastewater Treatment, Journals of materials Science Research, ISSN : 1927-0585, EISSN : 1927-0593, Volume 1, No.1; January 2012.

[2] 2 Kavitha.s, dr.t.felix kala, Study on structure and extraction of bamboo fiber as strength enhancer in concrete, IJRET, e-ISSN : 2319-1163, pISSN:23217308, Volume:03, Issue: 01, January 2014.

[3] Amit Rana, Some Studies on Steel Fiber Reinforced Concrete, IJETAE, ISSN: 2250-2459, ISO 9001:2008 certified, Volume 3, Issue 1, January 2013.

[4] Ronald f. Zollo, Reviews on fibre reinforced concrete, (1997).

[5] H. Abdul Khalil, I. Bhat, M. Jawaid, A. Zaidon, D. Hermawan, and Y. Hadi, "Bamboo fibre reinforced biocomposites: A review," Materials \& Design, vol. 42, pp. 353-368, 2012.

[6] J J. Janssen, Designing and building with bamboo: International Network for Bamboo and Rattan China, 2000.

[7] Nguyen Van CHANH, Steel Fiber Reinforced Concrete, Faculty of Civil Engineering, Ho Chi Minh City University of Technology.

[8] Divyesh kumar D. Paradava, Prof.Jayeshkumar Pitroda, Utilization of Artificial fibres in Construction Industry : A Critical Literature Review, ISSN : 22315381 IJETT- Volume 4 Issue 10- Oct 2013.

[9] K.Srinivasa Rao, S.Rakesh kumar, A.Laxmi Narayana V, Comparison of Performance of standard concrete and Fibre Reinforced Standard Concrete Exposed To Elevated Temperatures, American Journal of Engieering Research(AJER) e-ISSN : 2320-0847 p-ISSN : 2320-0936 Volume-02, Issue-03, pp-20-26

[10] Yalley.P.P and Kwan, A.S.K, Use of Coconut Fibre As An Enhancement Of Concrete, School of Engineering, Cardiff University, UK.

[11] Chuan Mein Wong, Use of Short Fibres in Structural Concrete to Enhance Mechanical Properties, University of Southern Queensland, Faculty of Engineering and Surveying, Course ENG 4111 and ENG 4112 Research Project, November, 2004. 